\title{
Intégrer l'infosurveillance, l'infodémiologie et une recherche interventionnelle conséquente dans nos systèmes de santé publique pour mieux protéger et promouvoir la santé de la population au Canada : idées et perspectives
}

\section{Integrating infoveillance, infodemiology, and consequential intervention research in our public health systems to better protect and promote the health of Canadians: ideas and perspectives}

\author{
Maryline Vivion $^{1,2}$ (D) . Lise Gauvin ${ }^{3,4}$ (D) \\ Received: 27 May 2021 / Accepted: 13 September 2021 / Published online: 3 January 2022 \\ (c) The Author(s), under exclusive licence to The Canadian Public Health Association 2021
}

\begin{abstract}
Résumé
Il ne fait désormais aucun doute que l'exposition au raz-de-marée d'informations en santé tantôt fondées sur les données probantes, tantôt sans fondement et même fallacieuses est un enjeu de santé publique. Le vocable infodémie est utilisé pour désigner ces phénomènes. Les études menées depuis deux décennies ont permis de mesurer l'ampleur de la surcharge d'informations et la qualité des informations auxquelles sont exposées les populations. Certains effets néfastes ont aussi été documentés. Il apparaît urgent de mobiliser et structurer les systèmes de santé publique en mobilisant toutes les expertises nécessaires à la lutte contre la désinformation en santé et la gestion de l'infodémie. Pour cela, nous lançons un appel à la réflexion autour de trois axes soit, l'infosphère comme un déterminant social de la santé, le développement de compétences en infodémiologie et finalement, le développement, la cocréation et l'évaluation d'interventions conséquentes pour mieux gérer l'infodémie et lutter contre la désinformation. Nous pensons que les leçons tirées collectivement d'une intégration
\end{abstract}

Ce commentaire est publié dans les deux langues officielles du Canada, la traduction ayant été fournie par les auteures. / This commentary is published in both official languages of Canada, the translation having been provided by the authors.

\section{Crédits / Credits}

La rédaction de ce commentaire n'a pas bénéficié d'un soutien financier. Il a toutefois été préparé en marge des Dialogues communautaires de l'Institut de santé publique et des populations des Instituts de recherche en santé du Canada (voir https://cihrirsc.gc.ca/f/52438.html) et soumis avant la tenue de l'événement portant sur l'infodémie et la confiance du public envers la science le 28 mai 2021. / The writing of this commentary was performed without financial support. However, the commentary was written in preparation for one of the Community Dialogue events led by the Institute for Population and Public Health of the Canadian Institutes of Health Research (see https://cihr-irsc.gc.ca/e/52438. html) and was submitted for publication before the event on Infodemics and Public Trust was held on May 28, 2021. None of the thoughtful comments raised during these dialogues are included in this commentary.

Extended author information available on the last page of the article 
réussie de l'infosurveillance, de l'infodémiologie et d'une recherche interventionnelle conséquente dans nos systèmes de santé publique serviront à mieux aborder les enjeux associés à l'infodémie.

\begin{abstract}
There is no longer any doubt that exposure to the tsunami of health information which is sometimes evidence-based and sometimes unfounded and even misleading, is a public health issue. The term infodemic is used to describe this phenomenon. Research conducted over the past two decades has provided a measure of the extent of information overload and of the quality of information to which populations are exposed. Selected harmful effects have also been observed. It is urgent to mobilize and structure public health systems by involving all the required expertise to combat health misinformation and better manage the infodemic. Towards this end, we are launching a call for critical thinking around three themes: the infosphere as a social determinant of health, the development of skills in infodemiology, and finally, the development, cocreation, and evaluation of consequential interventions to better manage the infodemic and combat disinformation. We believe that lessons learned collectively from the successful integration of infoveillance, infodemiology, and consequential intervention research in our public health systems will serve to better address issues emerging from infodemics.
\end{abstract}

Mots-clés Infodémie $\cdot$ infodémiologie $\cdot$ désinformation · mésinformation · protection de la santé · promotion de la santé confiance envers la science $\cdot$ inégalités sociales de santé

Keywords Infodemic $\cdot$ Infodemiology $\cdot$ Disinformation $\cdot$ Misinformation $\cdot$ Health protection $\cdot$ Health promotion $\cdot$ Trust in science $\cdot$ Social inequalities

\section{Introduction}

Le partage et l'utilisation de connaissances scientifiques tant avec les décideurs et les intervenants que le grand public sont des activités essentielles dans tout système de santé publique fondé sur les données probantes. Outre la croissance de la disponibilité de nouvelles connaissances due au nombre de périodiques scientifiques et au mouvement vers le libre-accès aux publications scientifiques, l'avènement de l'internet et des réseaux sociaux s'est conjugué avec les moyens déjà très répandus de diffuser les connaissances scientifiques (i.e., reportages, radios et événements télévisuels du domaine des nouvelles) créant ainsi un raz-de-marée d'informations qu'on désigne sous le vocable d'infodémie. De plus, des phénomènes de mésinformation, de désinformation et de fausses nouvelles se sont multipliés, tant avant que durant la pandémie de la COVID-19, suscitant des inquiétudes quant à leurs conséquences pour la santé des populations et l'accroissement des inégalités sociales de santé tout en mettant en péril la confiance du public envers la science. C'est dans ce contexte que le domaine de l'infodémiologie, soit l'étude des déterminants et de la distribution de l'information, la mésinformation et la désinformation en santé a émergé il y a déjà deux décennies (Eysenbach, 2002). Or, malgré les avancées importantes réalisées dans le recueil, le traitement et l'analyse des données relatives au flux considérable d'informations, il n'existe pas de consensus sur les moyens et stratégies à mettre en œuvre afin d'assurer la protection et la promotion de la santé des populations dans le contexte d'un fléau de mésinformation/désinformation/fausses nouvelles. Dans ce commentaire, nous lançons un appel à l'action pour intégrer l'infosurveillance, l'infodémiologie et une recherche interventionnelle conséquente dans les systèmes de santé publique au Canada.

\section{D'abord utiliser les bons termes}

La pandémie de la COVID-19 a mis en exergue l'enjeu de la quantité massive d'informations qui circulent sur la santé et ses déterminants de même que sur le traitement et la prévention des maladies. Cette prolifération d'informations n'est pas nouvelle ni spécifique à la crise sanitaire de COVID19. Elle avait déjà été mise en évidence par des études utilisant des techniques d'analyse des contenus journalistiques et des médias sociaux (Eysenbach, 2011). Toutefois, grâce aux avancées de l'infodémiologie, on sait maintenant comment mieux les définir et les catégoriser. Ainsi, une information réfère à un renseignement obtenu par le biais d'observations colligées de façon rigoureuse et qui peut être vérifié par une trame factuelle (Davenport, 2010). La mésinformation désigne des faits inexacts ou trompeurs, considérés comme véridiques par l'émetteur alors que la désinformation réfère à des informations erronées diffusées avec la volonté de tromper ou de nuire (Parsons Leigh, 2021). Certains auteurs ont caractérisé les fausses nouvelles comme désignant la fabrication d'informations imitant des vraies nouvelles (Lazer et al., 2018) et d'autres proposent que les théories du complot ont leurs origines 
dans la diffusion de désinformation qui a pour logique de considérer l'information officielle comme une tentative de désinformation intentionnelle et collective des autorités en place (Alaphilippe, 2020).

\section{L'infodémiologie : vers une science de l'infodémie}

En appliquant des méthodes quantitatives scientifiques et parfois en empruntant des modèles issus de l'épidémiologie des maladies infectieuses, l'infodémiologie avance les connaissances sur le volume et la circulation d'informations (incluant la vélocité et la qualité des informations) qui sont véhiculées par différents médias (Cinelli et al., 2020). L'infosurveillance elle, renvoie à la documentation des différents types d'informations et leurs lieux de diffusion en utilisant les méthodes reconnues de surveillance pour en comprendre l'évolution et les fluctuations. Dans une recension récente de 338 écrits, Mavragani (2020) montre que l'infodémiologie est un domaine en croissance rapide avec une augmentation marquée de publications scientifiques. Elle démontre aussi que les thématiques de santé examinées sont nombreuses et vont bien au-delà des maladies infectieuses. $\grave{A}$ ce propos, nous notons le lancement d'un nouveau périodique nommé : JMIR Infodemiology (https://infodemiology.jmir. org/about-journal/focus-and-scope) qui aura certes comme impact d'accélérer ces développements, renforcer davantage les méthodes et de multiplier les publications scientifiques sur l'infodémie dans plusieurs périodiques en santé publique.

Différents auteurs suggèrent que les médias sociaux tels que Facebook, Twitter, Instagram ou encore YouTube favorisent la diffusion de désinformations et que de nombreux thèmes sont touchés par ce phénomène (Suarez-Lledo \& Alvarez-Galvez, 2021; Mavragani, 2020; Cinelli et al., 2020). Les plus fréquents sont la vaccination, les régimes et les troubles alimentaires, les drogues et les nouveaux produits du tabac, les pandémies et les maladies infectieuses, ou encore les maladies non transmissibles et les traitements médicaux (Suarez-Lledo \& Alvarez-Galvez, 2021). Cependant, la prévalence de désinformations varie selon la plateforme. La prévalence d'événements de désinformation sur la vaccination, les drogues ou les pandémies semblent plus élevée sur les sites de microblogging tels que Twitter, alors que les plateformes de réseautage tels que Facebook favorisent la désinformation sur les maladies non transmissibles ou encore les traitements médicaux (Suarez-Lledo \& Alvarez-Galvez, 2021). Les médias sociaux sont pointés du doigt comme responsable de la diffusion de mésinformation/désinformation/fausses nouvelles. Or, bien qu'il y ait diffusion d'informations erronées sur les réseaux sociaux, plusieurs suggèrent qu'elles n'en sont que les moyens et pas la cause - les causes de mésinformation/désinformation/ fausses nouvelles se situeraient davantage dans les motifs entretenus par les personnes et organisations qui bénéficient de la diffusion de mésinformations et de désinformations. En outre, Morley et al. (2020) proposent que l'exposition à des infosphères de différentes qualités devrait être considérée comme un déterminant social de la santé.

En effet, la croyance et la diffusion de la désinformation sont associées à plusieurs facteurs. Par exemple il semble que ceux ayant un niveau de scolarité inférieur au secondaire ou ceux vivant seuls seraient plus vulnérables à la désinformation et plus susceptibles de les partager (Chowdhury et al., 2021; Hong \& Kim, 2020) - des inégalités sociales qui sont présentes pour de nombreuses problématiques de santé publique.

\section{Documenter et comprendre les effets de l'infodémie et de la désinformation}

Non seulement faut-il agir pour lutter contre la mésinformation et la désinformation, mais il importe aussi de constater que mieux comprendre l'infodémie qui sévit à un moment précis dans le temps recèle un potentiel considérable pour orienter l'intervention de santé publique. On sait que les recommandations émises par les autorités de santé publique peuvent et doivent évoluer au fur et à mesure des avancées scientifiques. En contexte pandémique, Eysenbach (2020) désigne ce phénomène comme la diffusion de BETs (Best Evidence at the Time). Les recommandations, continuellement et rapidement ajustées en fonction des BETs, peuvent entraîner auprès de la population de la confusion, de l'incompréhension ou bien du scepticisme (Malecki et al., 2020). Ensuite, les rumeurs ou fausses nouvelles peuvent éroder la confiance à l'égard des autorités de santé publique, générer de l'anxiété, de la peur ou encore la dépression (Eysenbach, 2020). De plus, les fausses nouvelles par leur forte charge émotionnelle accaparent l'attention et peuvent détourner des informations scientifiquement fondées et pertinentes (Jaubert \& Dolbeau-Bandin, 2020). Les fausses nouvelles peuvent entraîner des pratiques dangereuses. Des décès ont été liés par exemple à l'ingestion de différentes substances perçues comme pouvant protéger du coronavirus et dont les bénéfices supposés ont été fortement relayés dans les médias sociaux (Islam et al., 2020). Par ailleurs, l'utilisation importante des médias sociaux semble être associée à l'adhésion à des théories du complot (Bridgman et al. 2020). Des études indiquent que l'adhésion à ces théories est, à son tour, fortement associée au non-respect des pratiques préventives pour se protéger de la contagion du coronavirus (e.g., lavage des mains fréquent, distanciation physique, port du couvre visage) (Bridgman et al., 2020; Allington et al., 2020; Freeman et al., 2020; Généreux, 2020). Enfin, des enjeux liés à la stigmatisation ont 
également été mis en évidence notamment à l'égard des personnes aînées et des personnes originaires d'Asie sur les médias sociaux (Jimenez-Sotomayor et al., 2020; Bruns et al., 2020; Rahman \& Jahan, 2020; Reny \& Barreto, 2020). La stigmatisation peut se traduire par des menaces ou des insultes, voire même de la violence physique, à l'égard des personnes stigmatisées affectant ainsi leur santé physique et mentale (Bruns et al., 2020). Comme tout phénomène ayant un impact sur la santé des populations, l'infodémie doit faire l'objet d'actions fondées sur les meilleures données probantes.

\section{Agir pour contrer les effets de l'infodémie : des stratégies à définir et à déployer}

Ainsi, l'infodémie, la désinformation et la mésinformation sont désormais de réels enjeux pour la santé publique, car l'exposition à des infosphères de différentes qualités peut à la fois être néfaste pour les individus en générant par exemple des états émotionnels négatifs et aussi nuire aux efforts de lutte contre différentes maladies infectieuses et chroniques en remettant en question les mesures sanitaires proposées. Plusieurs cadres ont été développés pour lutter contre l'infodémie et la désinformation (Organisation mondiale de la Santé, 2020a; Schillinger et al., 2020; Eysenbach, 2020; Kirk Sell et al., 2021). Parmi ceux-ci, l'OMS a établi un agenda de lutte contre l'infodémie en contexte de pandémie, basé sur différentes étapes qui combinent l'infodémiologie, la compréhension des besoins et des inquiétudes de population, le développement d'interventions, et de partenariats avec des acteurs clés du milieu des médias sociaux et des plateformes technologiques (Organisation mondiale de la Santé, 2020b). À ces quatre piliers s'ajoute l'importance d'avoir une gestion coordonnée pour la production, la vérification et la diffusion des informations. En effet, dans l'urgence de lutter contre la mésinformation et la désinformation en contexte de pandémie, plusieurs initiatives ont été déployées. Certaines initiatives visent à vérifier les informations qui circulent sur Internet (Fact checking) (Society of Professional Journalists, 2021), d'autres utilisent les médias sociaux pour véhiculer des informations qui s'appuient sur la science telle que ScienceUpFirst (Science Up First, 2021) ou encore des sites Internet offrant des outils pour lutter contre la désinformation (Ryerson University Social Media Lab, 2020). L'urgence d'agir a permis le déploiement d'initiatives ponctuelles dont on connait peu l'implantation et les effets. Notamment, la portée, l'efficacité, l'acceptabilité et la pérennisation de ces initiatives et de leurs prédécesseurs visant à mitiger les effets de la désinformation n'ont pas encore été évaluées grâce à une recherche interventionnelle bien conceptualisée, réalisée et scientifiquement diffusée.

\section{Comment avancer?}

La crise récente a mis en relief l'infodémie, la mésinformation et la désinformation et des enjeux qu'elles soulèvent en minant la confiance du public envers la science en général et la santé publique fondée sur les données probantes en particulier. Le contexte sociopolitique et notamment la confiance envers les institutions et les autorités de santé publique jouent un rôle majeur pour contrer la désinformation (Enria et al., 2020). La lutte contre l'infodémie et la désinformation mobilise différentes expertises, que ce soient des domaines des sciences sociales (anthropologie, sociologie, sciences politiques), des sciences du comportement, des sciences des communications, de l'intelligence artificielle mais aussi les domaines de l'éthique et du juridique. C'est pourquoi il apparaît essentiel pour les organisations de santé publique de se positionner à l'égard de ce phénomène. Pour cela, il est nécessaire de coordonner les efforts de toutes les parties-prenantes et, à l'instar d'autres auteurs (Eysenbach, 2020; Kirk Sell et al., 2021), nous incitons les chercheurs et acteurs de la santé publique de même que d'autres acteurs sociétaux à débattre et échanger sur les enjeux suivants : l'intégration de l'infodémiologie et l'infosurveillance dans le coffre à outils des acteurs de la santé publique, l'acquisition de nouvelles compétences en lien avec l'infodémie et la désinformation et le développement et la cocréation d'interventions pour mieux gérer l'infodémie, lutter contre la désinformation et favoriser une utilisation éthique et efficace des médias sociaux pour protéger et promouvoir la santé des populations. Ces débats et échanges multipartites permettront alors de développer des plans d'action spécifiques pour coordonner et structurer les efforts des acteurs de la santé publique tout en concertant ces efforts avec ceux d'autres acteurs sociétaux pour la lutte contre l'infodémie et la désinformation.

\section{Conclusion}

La multiplication des technologies numériques et la diversification des moyens de partager l'information ont permis d'accélérer la communication. Or, dans tout système complexe, les transformations n'ont pas qu' un effet singulier mais des effets collatéraux attendus et inattendus. Nous proposons des actions pour permettre aux chercheurs et acteurs de la santé publique d'assumer pleinement leurs rôles d'acteurs sociétaux dédiés à l'amélioration de la santé et de l'équité des populations. Nous pensons que les leçons tirées collectivement d'une intégration réussie de l'infosurveillance, de l'infodémiologie et d'une recherche interventionnelle conséquente dans nos systèmes de santé publique serviront à mieux aborder la multitude d'enjeux et d'occasions soulevée par la montée de l'infodémie relative à différents problèmes de santé. 


\section{Integrating infoveillance, infodemiology, and consequential intervention research in our public health systems to better protect and promote the health of Canadians: ideas and perspectives}

\section{Introduction}

Knowledge transfer and exchange of scientific knowledge with policy-makers and practitioners as well as the public are essential activities of any evidence-based public health system. Aside from the growth of new knowledge associated with the increased number of scientific journals and the movement towards open access of scientific publications, the advent of the Internet and social media combined with existing and widespread means of disseminating scientific knowledge (i.e., broadcasts, radio and television events, newspapers) has created a tsunami of information called "infodemic". In addition, the phenomena of misinformation, disinformation, and fake news swelled both before and during the COVID-19 pandemic, thus eliciting concerns regarding their consequences for population health and social inequalities which in turn can jeopardize public trust in science. The field of infodemiology, the study of the determinants and distribution of information, misinformation, and disinformation, emerged in this context about two decades ago (Eysenbach, 2002). Despite substantial advances in the means of collecting, curating, and analyzing data pertaining to the ongoing influx of information, there is still no consensus regarding the means and strategies to implement in order to protect and promote the health of the population in the context of the increasing scourge of misinformation/disinformation/fake news. In this commentary, we call for action to integrate infoveillance, infodemiology, and consequential intervention research into public health systems in Canada.

\section{Priority 1: using the right words}

The COVID-19 pandemic highlighted the massive quantity of information circulating about health and its determinants as well as the treatment and prevention of different diseases. This proliferation of information is not new nor is it specific to the COVID-19 crisis. It had already been highlighted through studies analyzing news and social media content (Eysenbach, 2011). However, thanks to advances in infodemiology, we now know how to define and categorize different types of information. Hence, information refers to evidence obtained through rigorously collected observations that can be verified by a factual storyline (Davenport, 2010). Misinformation designates inaccurate or misleading facts that are considered true by the issuer whereas disinformation refers to incorrect information that is shared with the intent of deceiving or harming (Parsons Leigh, 2021). Selected authors have characterized fake news as being fabricated information that mimics real news (Lazer et al., 2018) and others propose that conspiracy theories consist of disinformation that is premised on the idea that official information is an attempt to intentionally and collectively misinform (Alaphilippe, 2020).

\section{Infodemiology: towards a science of infodemics}

By applying scientific quantitative methods and sometimes applying infectious disease models, infodemiology advances knowledge about the volume and circulation of information (including the velocity and quality of information) that is disseminated through different outlets (Cinelli et al., 2020). Infoveillance refers to the monitoring of different types of information and their means of dissemination by applying accepted methods of disease surveillance to ascertain information evolution and fluctuations. In a recent review of 338 studies, Mavragani (2020) shows that infodemiology is a rapidly growing area of investigation with rapidly increasing numbers of scientific publications. This review also reveals that infodemiologic research extends beyond infectious diseases and addresses many other health issues. We note the launching of a new scientific journal called JMIR Infodemiology (https://infodemiology.jmir.org/ about-journal/focus-and-scope) which will likely result in accelerating advancements, strengthening infodemiologic methods, and increasing the number of infodemiologic publications in many public health journals.

Different authors suggest that social media platforms like Facebook, Twitter, Instagram, or YouTube foster the dissemination of disinformation on a variety of health issues (Suarez-Lledo \& Alvarez-Galvez, 2021; Mavragani 2020; Cinelli et al., 2020). The most frequently discussed topics include vaccination, diets and eating disorders, drugs and new tobacco products, pandemics and infectious diseases, and non-communicable diseases and medical treatments (Suarez-Lledo \& Alvarez-Galvez, 2021). However, the prevalence of disinformation varies across platforms. The prevalence of disinformation on vaccination, drugs, and pandemics appears to be greater on microblogging platforms like Twitter, whereas platforms like Facebook appear to 
share disinformation about non-communicable diseases and medical treatments (Suarez-Lledo \& Alvarez-Galvez, 2021). Social media platforms are sometimes singled out as responsible for the dissemination of misinformation/ disinformation/fake news. Yet, although erroneous information does get disseminated on social media platforms, others suggest that they are merely the means rather than the causes of the problem - the causes of misinformation/disinformation/ fake news are more likely linked to the motives of the persons and organizations that benefit from the dissemination of misinformation and disinformation. Morley et al. (2020) even propose that exposure to different infospheres (quantity and variety of information sources) should be considered a social determinant of health.

Indeed, believing in and disseminating disinformation is associated with many factors. For example, some evidence shows that persons with less than a high school education, and individuals living alone are more vulnerable to disinformation and more susceptible to sharing disinformation (Chowdhury et al., 2021; Hong \& Kim, 2020) - a social patterning which is present for numerous public health issues.

\section{Researching and understanding the effects of the infodemic and disinformation}

Above and beyond addressing issues of misinformation and disinformation, a better understanding of infodemics can provide actionable evidence for building public health interventions. It is well known that guidelines issued by public health authorities can and should evolve according to the emergence of new scientific evidence. In the context of pandemics, Eysenbach (2020) refers to this phenomenon as the dissemination of BETs (Best Evidence at the Time). Unfortunately, the ongoing and rapid updating of guidelines as a function of BETs can lead to confusion, incredulousness, and even scepticism in the population (Malecki et al., 2020). Furthermore, rumours or fake news can erode confidence towards public health authorities, and generate anxiety, fear, or even depression (Eysenbach, 2020). Additionally, because they are emotionally charged, fake news excerpts attract attention and can detract from scientifically based and relevant information (Jaubert \& Dolbeau-Bandin, 2020). Fake news can also lead to dangerous practices. Some deaths have been linked to the ingestion of substances perceived to protect against the coronavirus, the benefits of which were widely shared on social media (Islam et al., 2020). Other research shows that greater use of social media is associated with stronger adherence to conspiracy theories (Bridgman et al., 2020). Some studies show that stronger adherence to conspiracy theories is associated with lesser adoption of preventive practices that can protect against contamination by the coronavirus (e.g., frequent handwashing, physical distancing, wearing a face mask) (Bridgman et al., 2020; Allington et al., 2020; Freeman et al., 2020; Genereux, 2020). Finally, issues related to stigmatization of seniors and persons from Asia as a result of social media messaging have been reported (Jimenez-Sotomayor et al., 2020; Bruns et al., 2020; Rahman \& Jahan, 2020; Reny \& Barreto, 2020). Stigmatized individuals can be the target of threats, insults, or even physical violence which clearly can impact their physical and mental health (Bruns et al., 2020). Like any other public health issue, infodemics must become the target of actions that are based on the best evidence.

\section{Defining and implementing strategies to counter the effects of the infodemic}

Consequently, infodemics, disinformation, and misinformation are undoubtedly real public health issues because exposure to infospheres of different quality can both negatively impact individuals by generating negative emotions and hamper efforts to fight different infectious and chronic diseases by resisting public health recommendations. Towards this end, different frameworks have been developed (Organisation mondiale de la Santé, 2020a; Schillinger et al., 2020; Eysenbach, 2020; Kirk Sell et al., 2021). Among these, the WHO has established a multistage agenda to address the infodemic in the context of the pandemic which combines infodemiology, the assessment of the needs and concerns of the population, the development of interventions, and partnerships with key actors from social media organizations and technological platforms (Organisation mondiale de la Santé, 2020b). In addition to these four pillars, the framework underscores the need for coordinated management in the production, verification, and dissemination of information. Indeed, many initiatives have been rapidly implemented to fight against misinformation and disinformation in the context of the pandemic. Selected initiatives aim to verify information circulating on the Internet (Fact checking) (Society of Professional Journalists, 2021), others involve using social media to disseminate information that is science-based like ScienceUpFirst (Science Up First, 2021), and other Internet sites offer tools to fight against disinformation (Ryerson University Social Media Lab, 2020). The urgent need for action has translated into one-time initiatives for which little is known regarding implementation and impact. That is, the reach, effectiveness, acceptability, and sustainability of these initiatives and their predecessors do not appear to be the object of any well-conceptualized, rigorously conducted, and scientifically shared intervention research. 


\section{Moving forward}

The recent COVID-19 crisis had highlighted the infodemic, misinformation, and disinformation as well as the threat they pose for trust in science generally and evidence-based public health in particular. The reigning socio-political contexts, and most notably confidence towards institutions and public health authorities, play a major role in countering disinformation (Enria et al., 2020). The fight against infodemics and disinformation should mobilize different expertises not only from the social sciences (anthropology, sociology, political science), behavioural science, communications sciences, and artificial intelligence but also from the fields of ethics and law. As a result, it seems essential for public health organizations to take a stand on these phenomena and to coordinate action among all stakeholders. Following the lead of other authors (Eysenbach, 2020; Kirk Sell et al., 2021), we call upon researchers and other actors in the public health system alongside other societal actors to debate and share ideas on the following issues: the integration of infodemiology and infoveillance in the toolbox of public health practitioners and policy-makers, the acquisition of new competencies related to the infodemic and disinformation, and the development and cocreation of interventions to better address infodemics, fight disinformation, and promote an effective and ethical use of social media to protect and promote population health. These multistakeholder debates and exchanges will allow for the development of specific action plans to coordinate and structure efforts of public health authorities while engaging with other societal actors to jointly fight infodemics and disinformation.

\section{Conclusion}

The availability of digital technologies and the diversification of means of sharing information have accelerated communications. As in all complex systems, these transformations have not had a single effect-rather, they have resulted in both expected and unexpected collateral impacts. We propose actions to allow public health researchers and actors to more fully assume their roles as societal actors dedicated to health improvement and equity at the population level. We believe that lessons learned collectively through a successful integration of infoveillance, infodemiology, and consequential intervention research in our public health systems will allow us to more effectively deal with the challenges and opportunities associated with the rise of infodemics related to different health issues.

\section{Declarations}

Conflit d'intérêts / Conflict of interest MV a reçu une subvention de recherche des Instituts de recherche en santé du Canada (subvention :
174884). LG est Directrice adjointe scientifique pour la santé des populations et Responsable du Carrefour de l'Innovation et de l'évaluation en santé au Centre de recherche du CHUM. LG est aussi membre du Conseil consultatif de l'Institut de santé publique et des populations des Instituts de recherche en santé du Canada. / MV is the recipient of a research grant from the Canadian Institutes of Health Research (Grant: 174884). LG is Associate Scientific Director for Population Health Research and Theme Leader for the Innovation and Evaluation Hub of the Centre de recherche du CHUM. LG is also a member of the Institute Advisory Board of the Institute for Population and Public Health of the Canadian Institutes of Health Research.

Approbation éthique / Ethics approval NA

Consentement à participer / Consent to participate NA

Consentement pour la publication / Consent for publication NA

Disponibilité des données et du matériel / Availability of data and material NA

Disponibilité du code / Code availability NA

Contributions des auteurs / Author contributions Les auteures ont contribué à la rédaction de ce commentaire. / The authors contributed to the writing of this commentary.

\section{Références / References}

Alaphilippe, A. (2020). European Disinfo Lab Resources for tackling misinformation about COVID-19. In Organisation mondiale de la Santé (Ed.), WHO consultation on Covid-19 infodemic management 7-8 avril 2020.

Allington, D., Duffy, B., Wessely, S., Dhavan, N., \& Rubin, J. (2020). Health-protective behaviour, social media usage and conspiracy belief during the COVID-19 public health emergency. Psychological Medicine 1-7 https://doi.org/10.1017/S003329172000224XPu

Bridgman, A., Merkley, E., Loewen, P., Owen, T., Ruths, D., Teichmann, L., et al. (2020). The causes and consequences of COVID19 misperceptions: Understanding the role of news and social media. The Harvard Kennedy School Misinformation Review, 1(Special Issue on COVID-19 and Misinformation) https://doi. org/10.37016/mr-2020-028

Bruns, D. P., Kraguljac, N. V., \& Bruns, T. R. (2020). COVID-19: Facts, cultural considerations, and risk of stigmatization. Journal of Transcultural Nursing, 31(4), 326-332. https://doi.org/10.1177/ 1043659620917724

Chowdhury, N., Khalid, A., \& Turin, T. A.-O. (2021). Understanding misinformation infodemic during public health emergencies due to large-scale disease outbreaks: A rapid review. Journal of Public Health (2198-1833) https://doi.org/10.1007/s10389-021-01565-3.

Cinelli, M., Quattrociocchi, W., Galeazzi, A., Valensise, C. M., Brugnoli, E., Schmidt, A. L., et al. (2020). The COVID-19 social media infodemic. Scientific Reports, 10(1), 16598. https://doi.org/ $10.1038 / \mathrm{s} 41598-020-73510-5$

Davenport, E. (2010).Confessional methods and everyday life information seeking. Annual Review of Information Science and Technology, 44(1), 533-562. https://doi.org/10.1002/aris.2010.14404 40119

Enria, L., Waterlow, N., Rogers, N., Brindle, H., Lal, S., Eggo, R., et al. (2020). Trust and transparency in times of crisis: Results from an online survey during the first wave (April 2020) of the 
COVID-19 epidemic in the UK - quantitative data. PLoS One, 16(2), e0239247. https://doi.org/10.1371/journal.pone.0239247

Eysenbach, G. (2002). Infodemiology: The epidemiology of (mis)information. American Journal of Medicine, 113, 763-765.

Eysenbach, G. (2011). Infodemiology and infoveillance: Tracking online health information and cyberbehavior for public health. American Journal of Preventive Medicine, 40(5S2), 154-158.

Eysenbach, G. (2020). How to fight an infodemic: The four pillars of infodemic management. [Commentary]. The Journal of Medical Internet Research, 22(6), e21820 https://doi.org/10.2196/21820.

Freeman, D., Waite, F., Rosebrock, L., Petit, A., Causier, C., East, A., et al. (2020). Coronavirus conspiracy beliefs, mistrust, and compliance with government guidelines in England. Psychological Medicine, 1-13, https://doi.org/10.1017/s0033291720001890

Genereux, M. (2020). COVID-19 : des troubles de stress et d'anxiété bien présents au Québec et au Canada, aggravés par la désinformation. Nouvelles $U d S$.

Hong, H. A.-O., \& Kim, H. J. (2020). Antecedents and consequences of information overload in the COVID-19 pandemic. International Journal of Environmental Research and Public Health, 17, https:// doi.org/10.3390/ijerph17249305

Islam, M. S., Sarkar, T., Khan, S. H., Mostofa Kamal, A.-H., Hasan, S. M. M., Kabir, A., et al. (2020). COVID-19-related infodemic and its impact on public health: A global social media analysis. The American Journal of Tropical Medicine and Hygiene, https://doi. org/10.4269/ajtmh.20-0812

Jaubert, E., \& Dolbeau-Bandin, C. (2020). Infox et Coronavirus Covid19 : une relative contagiosité ? HAL Archives ouvertes, Crises sanitaires et environnementales. https://hal.archives-ouvertes.fr/ hal-02542132/document. Accessed 13 Apr 2020.

Jimenez-Sotomayor, M. R., Gomez-Moreno, C., \& Soto-Perez-deCelis, E. (2020). Coronavirus, ageism, and Twitter: An evaluation of tweets about older adults and COVID-19. Journal of the American Geriatrics Society, 68, 1661-1665. https://doi.org/10. 1111/jgs. 16508

Kirk Sell, T., Hosangadi, D., Smith, E., Trotochaud, M., Vasudevan, P., Gronvall, G., et al. (2021). National priorities to combat misinformation and disinformation for COVID-19 and future public health threats: A call for a national strategy. The Johns Hopkins Center for Health Security. https://www.centerforhealthsecurity.org/ourwork/publications/national-priorities-to-combat-misinformationand-disinformation-for-covid-19. Accessed 12 Apr 2021.

Lazer, D. M. J., Baum, M. A., Benkler, Y., Berinsky, A. J., Greenhill, K. M., Menczer, F., et al. (2018). The science of fake news. Science, 359(6380), 1094-1096. https://doi.org/10.1126/science. aao2998

\section{Authors and Affiliations}

\section{Maryline Vivion $^{1,2}$ (D) - Lise Gauvin ${ }^{3,4}$ D}

\section{Maryline Vivion}

Maryline.vivion@inspq.qc.ca

1 Institut National de Santé Publique du Québec (INSPQ), Québec, Québec, Canada

2 Département de Médecine Sociale et Préventive de l'Université Laval, Québec, Québec, Canada
Malecki, K. M. C., Keating, J. A., \& Safdar, N. (2020). Crisis communication and public perception of COVID-19 risk in the era of social media. Clinical Infectious Diseases, https://doi.org/10. $1093 / \mathrm{cid} / \mathrm{ciaa} 758$

Mavragani, A. (2020). Infodemiology and infoveillance: Scoping review. The Journal of Medical Internet Research, 28(22), e16206., doi:https://doi.org/10.2196/16206.

Morley, J., Cowls, J., Taddeo, M., \& Floridi, L. (2020). Public health in the information age: recognizing the infosphere as a social determinant of health. The Journal of Medical Internet Research, 22(8), e19311. https://doi.org/10.2196/19311

Organisation mondiale de la Santé. (2020a). Infodemic managementInfodemiology. https://www.who.int/teams/risk-communication/ infodemic-management. Accessed 13 April 2020.

Organisation mondiale de la Santé. (2020b). Managing the COVID19 infodemic, Call for Action. https://www.who.int/news/item/ 11-12-2020-call-for-action-managing-the-infodemic. Accessed 30 April 2020.

Parsons Leigh, J. (2021). Sensibiliser, mobiliser et outiller : des repères pour la population face à l'infodémie et à la COVID-19. https:// cihr-irsc.gc.ca/f/51971.html. Accessed 18 May 2021.

Rahman, A., \& Jahan, Y. (2020). Defining a 'risk group' and ageism in the era of COVID-19. Journal of Loss and Trauma, 1-4, https:// doi.org/10.1080/15325024.2020.1757993

Reny, T. T., \& Barreto, M. A. (2020). Xenophobia in the time of pandemic: Othering, anti-Asian attitudes, and COVID-19. Politics, Groups, and Identities, 1-24, https://doi.org/10.1080/21565503. 2020.1769693

Ryerson University Social Media Lab. (2020). COVID19MISINFO. ORG https://covid19misinfo.org/. Accessed 26 May 2021.

Schillinger, D., Chittamuru, D., \& Ramírez, A. S. (2020). From "infodemics" to health promotion: A novel framework for the role of social media in public health. American Journal of Public Health, 110(9), 1393-1396. https://doi.org/10.2105/AJPH.2020.305746

Science Up First. (2021). Science Up First. https://www.scienceupfirst. com/en/scienceupfirst. Accessed 3 May 2021.

Society of Professional Journalists. (2021). Journalist's Toolbox. https://www.journaliststoolbox.org/. Accessed 3 May 2021.

Suarez-Lledo, V., \& Alvarez-Galvez, J. (2021). Prevalence of health misinformation on social media: Systematic review. [Review]. The Journal of Medical Internet Research, 23(1), e17187. https://doi. org/10.2196/17187.

Publisher's note Springer Nature remains neutral with regard to jurisdictional claims in published maps and institutional affiliations.

3 Département de Médecine Sociale et Préventive, École de Santé Publique de l'Université de Montréal (ESPUM), Montréal, Québec, Canada

4 Centre de recherche du Centre Hospitalier de l'Université de Montréal (CRCHUM), Montréal, Québec, Canada 